\title{
Agency Theory, Accounting Information, and Corporate Financial Management: A New Framework for Developing Financial Strategies for Banking Companies
}

\author{
CHOIRUNNISA ARIFA* \\ Universitas Gadjah Mada
}

\begin{abstract}
The objective of this study is to develop a corporate financial optimization model, based on the theoretical foundations of, and for integrating, the crucial issues in accounting and finance such as agency and information asymmetry and the use of accounting information to mitigate the problems, which can give appropriate financial strategies relevant for the contemporary business world. There are a good number of financial models in the existing literature. However, as important issues relevant to financial management for corporations are emerging, it is essential to develop a financial optimization model that can embed and address these emerging issues and can prescribe a set of financial management strategies, which are relevant in the current situations of corporations shaped by these emerging issues. This study formulates an applied integrated financial optimization problem to investigate the extent to which the financial model designs optimal financial strategies that can mitigate agency problems and provide a basis for sound accounting practices, leading to the optimal company value in real life situations. Generally, this study concludes that the integrated financial model can provide economic significance when formulating financial strategies for mitigating agency problems and maximizing company value. It also provides new insights into sound accounting practices should be implemented in an integrated, large-scale real-life financial strategy. This paper contributes to corporate financial modeling by developing a model based on the multidisciplinary literature, including contemporary accounting, agency theory, and management science, by providing a new corporate finance model, which is appropriate for modeling and addressing some crucial contemporary issues in corporate finance in the current world.
\end{abstract}

Keywords: Accounting Information, Agency Theory, Agency Problems, Optimization Model, Corporate Finance, Financial Management.

Intisari: Tujuan dari penelitian ini adalah untuk mengembangkan model optimasi keuangan perusahaan, berdasarkan pada landasan teoritis, dan untuk mengintegrasikan isu-isu penting dalam akuntansi dan keuangan seperti asimetri agensi dan informasi dan penggunaan informasi akuntansi untuk mengurangi masalah, yang dapat memberikan strategi keuangan yang tepat yang relevan untuk dunia bisnis kontemporer. Ada sejumlah model keuangandalamliteratur yang

* Corresponding author : choirunnisa_a@ugm.ac.id 
sudahada. Namun, karena isu-isu penting yang relevan dengan manajemen keuangan untuk perusahaan sedang berkembang, penting untuk mengembangkan model pengoptimalan keuangan yang dapat menanamkan dan mengatasi masalah yang muncul dan dapat meresepkan serangkaian strategi manajemen keuangan, yang relevan dalam situasi perusahaan saat ini. dibentuk oleh isu-isu yang muncul ini. Studi ini merumuskan masalah optimasi keuangan terintegrasi yang diterapkan untuk menyelidiki sejauh mana model keuangan merancang strategi keuangan yang optimal yang dapat mengurangi masalah keagenan dan menyediakan dasar untuk praktik akuntansi yang baik, yang mengarah ke nilai perusahaan yang optimal dalam situasi kehidupan nyata. Umumnya, penelitian ini menyimpulkan bahwa model keuangan terintegrasi dapat memberikan signifikansi ekonomi ketika merumuskan strategi keuangan untuk mengurangi masalah keagenan dan memaksimalkan nilai perusahaan. Ini juga memberikan wawasan baru ke dalam praktik-praktik akuntansi yang baik harus diterapkan dalam strategi finansial kehidupan nyata berskala besar yang terintegrasi. Makalah ini memberikan kontribusi untuk pemodelan keuangan perusahaan dengan mengembangkan model berdasarkan literatur multidisiplin, termasuk akuntansi kontemporer, teori keagenan dan ilmu manajemen, dengan menyediakan model keuangan perusahaan baru, yang sesuai untuk pemodelan dan mengatasi beberapa isu kontemporer yang krusial dalam keuangan perusahaan. di dunia saat ini.

Kata kunci: Informasi Akuntansi, Teori Agensi, Masalah Keagenan, Model Optimasi, Keuangan Perusahaan, Manajemen Keuangan.

\section{Introduction}

Banking companies as financial institutions operate in a specific business environment that has unique risk characteristics compared to other industries. These are related to the vast array of uncertainties exposed in their operations, including the rapid changes in the financial market, financial regulatory reforms and the globalization of financial flows which can cause banks to become the most troubled institutions in economies (Van Greuning and Bratanovic 2009; Rethel and Sinclair 2012). Based on the perspectives of business and economics, banks are also facing the common problem, which is the way individuals (or business entities as a whole) should allocate their limited resources and uncertain business environment to satisfy their unlimited and competing desires; hence there is a necessity for the decision makers to formulate the best strategy to deal with, through an optimal corporate 
financial model (Moss 2010). However, in achieving the best strategies that can optimize the financial performance, companies cannot neglect the crucial emerging issues in accounting, finance, capital market and business environments such as agency problems and information asymmetry and the use of financial accounting information to mitigate those problems, as discussed below.

According to the agency theory perspective, modern corporations, including publicly-owned banks, are facing agency problems sourced from the asymmetric information between a principal (i.e. shareholders) and an agent (i.e. managers) in the decision-making process, which might lead to an incomplete contract as the consequence of random disturbances on the outcome of their decisions, including inefficient behavior of all parties (i.e. shareholders and managers) in satisfying their own interests (Holmstrom and Tirole 1989; Schroeck 2002). Eisenhardt (1989) argues that, in the presence of asymmetric information, the agency problem can create incomplete contracting with the organization leads to the goal conflict, increased outcomes uncertainty and decreased outcomes measurability. Thus, decision makers have to consider all contributing variables in the process that can address and mitigate the agency problems, hence can ensure a complete contracting between shareholders and managers.

Related to the issue, Brown (2011) argue that both parties (management and shareholders) need to share some information about the actual financial position and performance of the company that might be relevant and can affect their decisions through a sound accounting information system. This system can provide accounting information that summarizes and inform the outcomes of management's past activities as an essential basis for estimating future performance on which shareholders may use as a basis for their investment decision. Hence, financial accounting information provides a significant role as intermediaries between managers and shareholders in communicating financial position and performance of the companies and hence reducing information asymmetry (Drever et al. 2007; Scott 2015). For banking companies specifically, the use of financial accounting information in developing financial strategies must also be supported by other key elements in banking financial 
management including the attraction of firm resources, liquidity and capital management, risk management and asset-liability management, hence the companies can achieve efficient allocation and management of financial resources that are necessary for their survival and growth (Kosmidou and Zopounidis 2004; Van Greuning and Bratanovic 2009; Rezaee 2011).

Previous studies suggest that corporate financial models have been developed to provide the best strategies to achieve the highest and most efficient financial performance. For example, Ijiri et al. (1963) develop a budgeting and financial planning model by employing a linear programming technique and integrate this technique with a double-entry accounting system. This model formulates strategies of planning and identifies the transaction flows that would bring a company to the best possible financial position at the end of an operational period. Further, Carleton et al. (1973) use accounting relationships to develop a more integrated model for corporate financial management, which emphasizes not only on solving management problems but also fulfilling shareholders' interests, reflected in the objective function by maximizing the value of the owners' equity. This model is probably the mostintegrated model in accounting and finance areas, as it has been cited and adopted by several studies into financial strategy formulations (e.g., Ho and Lee 2004; Lee et al. 2009; Nuryanah and Islam 2015). However, none of these models are built in the banking context.

Early 1960s, Chambers, and Charnes (1961) employ a linear programming model to solve balance sheet management problems for banking companies, by maximizing profit subject to satisfying the minimum capital adequacy and reserve requirement. This study is followed and extended by studies by Cohen and Hammer (1967), which applies an intertemporal linear programming model as a managerial apparatus to obtain the optimal asset management decisions in a commercial bank and Crane (1971), which proposes a stochastic programming approach to solve the bond portfolio management problem under uncertainty economic condition. In further studies, the bank's management becomes more complex and is often challenged by somewhat competing and conflicting goals such as returns maximization and minimization of 
risk associated with alternative asset-liability portfolio combination. Therefore, the proposed model formulates the objective function as minimizing the deviations from satisfying all management goals. This technique is implemented in further advanced research in the similar area, for example, Langen (1989), Jedicke et al. (1994), Korhonen (2001), Kosmidou and Zopounidis (2004) and Chakroun and Abid (2013).

Nevertheless, none of these studies consider the contemporary issues that are crucial and remains relevant in the current development of corporate finance theory, including agency problems and information asymmetry and the use of accounting information, which can significantly affect the way a banking company formulates its financial strategies. Motivated by the gap, this study strives to develop a financial model for banks, which is based on the agency theory to address the issues of agency problems and information asymmetry, by using an accounting information system. The development of the financial model is aimed to investigate further the way this approach can mitigate the agency problems, strengthen the financial position and improve the financial performance in the sense of company value. Accordingly, this study can extend the body of knowledge in accounting, finance, management science and financial management for financial institutions.

The investigation and analyzes are conducted using an integrated financial optimization approach within the framework of agency theory, accounting, and finance. This methodology is chosen due to its usefulness in providing an integrated understanding of the way agency relationships, and sound accounting information system should be incorporated into a corporate financial model to achieve the optimal financial strategies leading to maximum company performance. To address the research issues above, this study conducts a case study by proposing a prescriptive economic optimization model, applicable for corporation-form banking companies, where the issues are of particular concern. Through a numerical case applied in the model, this study strives to explain how the model can be implemented in practice and what results and implications can be obtained from the model for formulating strategies in a banking company. 
The rest of the paper is organized as follows. The conceptual and modeling framework for developing an integrated financial optimization model is discussed in the next section. Section 3 discusses the research methodology and empirical data. Section 4 presents the development of the financial optimization model in a corporation as a case study. Section 5 presents the model testing and analysis tool for solving the linear programming problem. Section 6 discusses analyses, discussions, and implications of the results of testing the model. Section 7 presents the model's verification and validation processes to examine the plausibility of the results and to generalize the model. Section 8 concludes the paper.

\section{Theoretical Framework and Hypothesis Development}

\subsection{Agency Theory, Information Asymmetry and Accounting Information}

As introduced by Berle et al. (1932), the agency theory argues that in a modern corporation, the separation between the owners and management has led to agency conflicts, where the agent (management) acquires more information and hence tends to act for their benefit, rather than satisfying the interests of the principal (shareholders). This conflict creates agency costs, arising from the principal monitoring the unusual activities of the agent and ensuring that the agent acts on their behalf and from the losses which occur as a result of the contrasting decisions taken by both the agent and the principal, as in the suboptimal allocation of resources (Jensen and Meckling 1976). From the corporate finance perspective, the agency theory through its signaling mechanism provides implications for corporate financing decisions, including the dividend policy, capital structure and so on (Copeland et al. 2005; Brealey et al. 2016).

According to the accounting perspective, the signaling mechanism represents the essential governance mechanism that can provide interested parties with information about a company's financial position and performance. This is achieved through a sound accounting information system, which produces financial accounting reports that summarize the results of the management's past activities as an essential basis for the estimation of future performance, which shareholders may use as a basis for their 
investment decisions(Brown et al. 2011). Furthermore, as accounting reports provide observable and verifiable information about the managers' performance, the agency theory argues that accounting reports have an essential role in helping monitor and control the actions of managers; hence the incentive contract needs to be linked with the accounting information (Scott 2015). In this way, the accounting information plays a significant role as an intermediary between managers and shareholders for communicating the financial position and performance of the company and hence reducing agency and information asymmetry problems (Drever et al. 2007; Scott 2015).

\subsection{Financial Optimization for Achieving Best Financial Strategies}

The existing literature reveals that the optimization approach is widely used as a managerial apparatus for modeling decision-making process. The use of this approach in various areas of strategic decision-making has been emerging since the approach itself is found up to present time. The very first corporate financial model as a tool for management information system is proposed by Gershefski (1969). This model can be used generally to prepare short-term profit plans and long-range projections by simulating the key financial indicators including income statement, capital investment schedule, statement of stockholders' equity and earnings employed, financial and operating summary, tax report and rate-of-return analysis. The model also can be used to address further problems of management interests, including enabling management to react quickly to events and to revise income estimates and other aspects of performance based on available budget. Further, Carleton et al. (1973) propose a financial model in which focuses not only solving management problems but also fulfilling shareholders' interest, reflected on an objective function by maximizing the value of owners' equity.

Although there has been an extensive development of corporate financial strategies employing the financial optimization model (e.g., Ijiri et al. 1963; Carleton et al. 1973; Nuryanah and Islam 2015), none of these has been developed under the specific assumptions of asymmetric information and agency problems. Accordingly, 
the existing models overlook the integration of the agency's relationship and incentive mechanisms into the model to capture the real problems of the decision-making process in a modern corporation, characterized by the underlying problems of agency and asymmetric information. Although some theoretical models for solving the agency problem in the accounting and finance areas have been developed (Khan 2015; Kanodia 2014; Demski 2008; Tirole 2001), these models have not been implemented in an integrated real-life applicable financial model. Consequently, there is a gap between these theoretical agency models (focusing on one or only a few variables) and the real world (Douma and Schreuder 2008); hence a new financial model applicable to a real-life, large-scale organization could provide an understanding of the agency theory's applications in resolving agency problems and achieving a more efficient governance structure.

\section{Research Method}

A financial optimization model is a mathematical model built to find the best possible strategy for a set of financial decisions. These decisions are restricted by a set of constraints on the values of the variables, such as sources of funding, capital, value of assets and so on. As the model is designed to achieve a specific goal from the limited amount of available resources, it can be used to support the processes of financial engineering and the extent to which they can develop sound financial strategies and build a strong institutional financial structure(Morris and Daley 2009; Zenios 2007).

The Linear Programming (LP) model is one of the mathematical optimization approaches with the main goal is to determine the optimal value of the decision variables that can maximize or minimize the objective's function. The result of the model is the best possible solution out of a set of alternatives under the restrictions of the constraints on the value of the variables(Koo 1977). Generally, a typical linear programming model for a maximization problem can be simply stated in the following form(Williams 2013): 


$$
\begin{array}{ll}
\text { Maximise } & z_{x}=c_{1} x_{1}+c_{2} x_{2}+\cdots+c_{n} x_{n}+d \\
\text { Subject to: } & a_{11} x_{1}+a_{12} x_{2}+\cdots+a_{1 n} x_{n} \leq b_{1}, \\
& a_{m} x_{1}+a_{m 2} x_{2}+\cdots+a_{m n} x_{n} \leq b_{m}, \\
& x_{j} \geq 0, \quad j=1,2, \ldots, n,
\end{array}
$$

Where $x_{1}, x_{2}, \ldots, x_{n}$ are the variables and $a_{i j}, b_{i}, c_{j}, d$ are given constants

This study simulates the financial model through a numerical case applied in the model, to explain how the model can be implemented in practice and what results and implications can be obtained from the proposed model for formulating strategies. This study conducts case-study analysis as its strategy, due to its usefulness in providing indepth analysis of the investigated research phenomena, in a banking company with a real financial data to show the applicability of the model. Further, a robust model should accommodate the sustainability issue of the financial trends in forecasting the future performance. As company value maximization can be influenced by the longterm nature of investing and financing activities, the effects of business cycles and other nonrecurring factors cannot be reliably measured in a one-year period analysis (Subramanyam and Wild 2014). Therefore, to satisfy the model, this study will use the 5-year financial data sourced from audited financial statements (i.e., the accounting numbers are valid and free from noise). All this data can be obtained from the company's annual reports. Any data which cannot be obtained from public sources are calculated and simulated based on reasonable assumptions from historical data and previous studies.

\section{Model Development and Specification ${ }^{1}$}

\subsection{The Variables and Parameters}

As the primary purpose of modeling financial management for banks is essentially for balance sheet management (Güven and Persentili 1997; Chi et al. 2007; Birge and Júdice 2013), the variables used in developing the financial model are

\footnotetext{
${ }^{1} \mathrm{~A}$ complete list of the definitions of the variables and parameters is given in Appendix 1
} 
mainly specified for that purpose. Accordingly, the variables of the model are categorized into four types, including decision variables of the objective function, decision variables representing assets, decision variables representing liabilities and other variables, which are derived from the accounts reported in the accounting system, as presented as follows.

1. Decision variables of the objective function

$\boldsymbol{d}_{\boldsymbol{t}} \quad$ : Dividend paid in period $\mathrm{t}$

2. Variables representing assets $\left(X_{1 n}\right)$

$\boldsymbol{X}_{\mathbf{1 1}_{\boldsymbol{t}}}$ : Loans, bills discounted and other receivables in period $\mathrm{t}$

$\boldsymbol{X}_{\mathbf{1 2}_{\boldsymbol{t}}}$ : Cash and liquid assets in period $\mathrm{t}$

$\boldsymbol{X}_{13} \boldsymbol{t}$ : Receivables due from other financial institutions in period $\mathrm{t}$

$\boldsymbol{X}_{\mathbf{1 4} \boldsymbol{t}} \quad$ : Securities in period $\mathrm{t}$

3. Variables representing liabilities $\left(X_{2 n}\right)$

$\boldsymbol{X}_{\mathbf{2 1}}$ : Deposits and other public borrowings in period t

$X_{22} t$ : Payables due to other financial institutions in period $\mathrm{t}$

$\boldsymbol{X}_{\mathbf{2 3} \boldsymbol{t}}$ : Debt issues in period $\mathrm{t}$

$\boldsymbol{X}_{\mathbf{2 4} \boldsymbol{t}}$ : Loan capital in period $\mathrm{t}$

4. Other variables $\left(X_{3}\right)$

$\boldsymbol{X}_{\mathbf{3}_{\boldsymbol{t}}} \quad$ : Remuneration paid to executives in period $\mathrm{t}$

The choice of variables is justified under the main assumptions that 1) the company consistently pays a dividend to its shareholders annually; 2) other elements of its balance sheet, including its non-interest earning assets, non-interest bearing liabilities and equities, are known based on the historical financial reports; and 3) the company does not issue new shares. Hence there is no change in the number of shares.

\subsection{Objective Function}

In this study, the proposed model is aimed at achieving the goal of corporate financial management, which is maximizing the company's value. As the model is 
developed within the framework of the agency theory, the objective function should reflect the shareholders' interest and relate with the concepts and parameters which are essential for the stakeholders to evaluate the management's performance(Stern 1972; Van Horne and Wachowicz 2005). The previous literature suggests that the most common method for valuing a company is by using the Discounted Cash Flow (DCF) method, which reflects the intrinsic value of the company, based on the projection of all the future cash flows which could be made available for investors (Titman et al. 2014; Brealey et al. 2016). However, as the model is applied to a banking company, the company's valuation method is adjusted to the banking context, by assuming that the sources of capital only consist of its equity capital, hence the company's valuation method in this study is through its equity's valuation by discounting any free cash flows to equity investors at the cost of equity (Damodaran 2013). Accordingly, based on the dividend discount model, the value per share of equity is specified by the present value of the expected dividend to be paid to the shareholders, discounted on the cost of equity capital during the observation periods, plus the present terminal price value of the equity, discounted by the cost of the equity capital at the end of observation period Accordingly, the objective function is expressed in a mathematical equation as follows:

$$
\begin{aligned}
\operatorname{Maximise} \sum_{t=1}^{n}\left[\frac{D P S_{t}}{(1+k e)^{t}}\right] \\
+\left[\frac{E_{n}}{(1+k e)^{n}}\right]
\end{aligned}
$$

Where $D P S_{t}$ : dividend per share at period $\mathrm{t}$

$k e$ : cost of equity used as the discount rate

$E_{n}$ : the terminal value of equity at the end of the observation period $\mathrm{n}$

\section{Constraints}

${ }^{2}$ The calculation of dividend per share, $D P S_{t}=\frac{d_{t}}{N_{t}} \quad$ and $E_{T}=\frac{d_{T}(1+g)}{\left(k_{e}-g\right)}$; where $g$ is the expected
dividend growth rate; and $k_{e}$ is calculated by using the capital asset pricing model (CAPM). 
a. Accounting identity constraints

\section{$\underline{\text { Income Statement }}$}

An income statement shows the result of the operational activities of a company during the accounting period $t$. In the banking context, performance is represented by net income, which is measured by the sum of the interest income generated from the assets $\left(I n t I n c_{t}\right)$ and the interest costs paid for all the funding sources $\left(\operatorname{Int} E x_{t}\right)$, with all the operating expenses and related taxes subtracted. If the corporate tax rate in period $\mathrm{t}$ is given as $\tau_{t}$, this relationship is presented as follows:

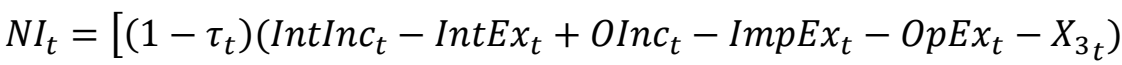

$$
\begin{aligned}
& \left.-\operatorname{PTax}_{t}\right]
\end{aligned}
$$

where:

$$
\begin{gathered}
\operatorname{IntInc}_{t}=y_{l} X_{11_{t-1}}+y_{r} X_{12 t-1}+y_{c l} X_{13 t-1} \\
+y_{s e c} X_{14 t-1} \\
\text { IntEx } x_{t}=i_{d} X_{21_{t-1}}+i_{a p} X_{22 t-1}+i_{d b} X_{23 t-1}+ \\
i_{l c} X_{24 t-1}
\end{gathered}
$$

Net income in period $\mathrm{t}\left(N I_{t}\right)$ should be a positive number, as it cannot be less than zero. Substituting equations (3) and (4) into equation (2), mathematically, this constraint can be expressed as $N I_{t} \geq 0$, or

$$
\begin{gathered}
\left(1-\tau_{t}\right)\left[y_{l} X_{11_{t-1}}+y_{r} X_{12_{t-1}}+y_{c l} X_{13_{t-1}}+y_{s e c} X_{14_{t-1}}\right. \\
-\left(i_{d} X_{21_{t-1}}+i_{a p} X_{22_{t-1}}+i_{d b} X_{23_{t-1}}+i_{l c} X_{24_{t-1}}\right)+O \operatorname{Inc}_{t} \\
\left.-\operatorname{ImpEx}_{t}-O p E x_{t}-R E x_{t}\right]- \text { PTax }_{t} \\
\geq 0
\end{gathered}
$$

\section{Balance Sheet}

This constraint reflects the position of the sources and uses of the funds as shown in the balance sheet(Ho and Lee 2004). Following the basic accounting equation, the relationship of the financial flows in year $t$ is presented as:

$$
\begin{aligned}
& \text { Assets }_{t}-\text { Liabilities }_{t} \\
& =\text { Equity }_{t}
\end{aligned}
$$


Where

$$
\begin{gathered}
\text { Assets }_{t}=X_{11_{t}}+X_{12_{t}}+X_{13_{t}}+X_{14 t} \\
+ \text { NonIA }_{t} \\
\text { Liabilities }_{t}=X_{21_{t}}+X_{22_{t}}+X_{23_{t}}+X_{24 t} \\
+ \text { NonIL }_{t} \\
\text { Equity }_{t}=S C_{t}+\text { Res }_{t}+R P_{t-1}+ \\
\Delta R P_{t}
\end{gathered}
$$

$S C_{t}$ denotes the share capital in period $\mathrm{t}, \operatorname{Res}_{t}$ denotes the reserves in period $\mathrm{t}$, and $R P_{t}$ denotes the retained profit in period t. $\Delta R P_{t}$ or the increase in retained earnings is obtained from subtracting net income in period $\mathrm{t}\left(N I_{t}\right)$ with the dividend paid in period $\mathrm{t}\left(d_{t}\right)$. Substituting equations (7), (8) and (9) into equation (6), accordingly, the theoretical balance sheet identity or the fund availability constraints (Brodt 1978) for the model are as follows:

$$
\begin{aligned}
\left(X_{11_{t}}+X_{12_{t}}+\right. & \left.X_{13_{t}}+X_{14_{t}}\right)-\left(X_{21_{t}}+X_{22_{t}}+X_{23_{t}}+X_{24_{t}}\right)+d_{t} \\
& =S C_{t}+\operatorname{Res}_{t}+R P_{t-1}+\text { NonIL }_{t}-\text { NonIA }_{t} \\
& +N I_{t}
\end{aligned}
$$

\section{Cash flows identity constraints}

This constraint shows the flow of cash produced in one accounting period and becomes the essential element for maintaining the equilibrium of the financial model (Morris and Daley 2009). The cash flow is represented by the Net Cash Inflow (NCI), which is available to be added to the cash account or to be paid as a dividend (Hamilton and Moses 1973). The NCI consist of 1) net Cash Flow from Operations (CFO); 2) net Cash Flow from Investments, assumed to be negative due to the active investments (CFI); and 3) net Cash Flow from Financing (CFF). This can be written as:

$$
\begin{aligned}
& N C I_{t} \\
& =C F O_{t}-C F I_{t} \\
& +C F F_{t}
\end{aligned}
$$


Inserting the accounting elements of $\mathrm{CFO}, \mathrm{CFI}$, and CFF into $\mathrm{NCI}$, the theoretical cash flow's identity or cash availability constraint (Brodt 1978) is given as:

$$
\begin{gathered}
{\left[\left(1-\tau_{t}\right)\left(\text { IntInc }_{t}-\text { IntEx }_{t}+O \operatorname{Inc}_{t}-O p E x_{t}-X_{3 t}\right)-P \text { Pax }_{t}\right.} \\
\left.-\left(\Delta X_{11_{t}}+\Delta X_{13_{t}}+\Delta X_{14_{t}}\right)+\left(\Delta X_{21_{t}}+\Delta X_{22_{t}}\right)\right] \\
-\left[\left(P P E_{t}-P P E_{t-1}\right)+\left(\text { IntAs }_{t}-\operatorname{IntAs}_{t-1}\right)\right] \\
+\left[\left(X_{23_{t}}-X_{23_{t-1}}\right)+\left(X_{24_{t}}-X_{24 t-1}\right)+\Delta S C_{t}-d_{t}\right] \\
\geq 0
\end{gathered}
$$

b. Agency relationships and governance mechanisms

\section{Executives remuneration/compensation scheme}

As discussed previously, the agency problem is characterized by the information asymmetry where the agent (i.e., the manager) tends to have more information than the principal (i.e., the shareholders) and the agent tends to do moral hazard by utilizing the unobservable information for their interests (Holmstrom 1979). In order to resolve the agency problem between the shareholders and managers, the principal needs to design an incentive contract (i.e. a remuneration scheme) that can motivate the managers to take actions on behalf of the shareholders' interests and allows shareholders to directly monitor the managers' performance (McGuigan et al. 2014; Samuelson and Marks 2015).

This study specifies the incentive contract constraints in two forms: managerial remuneration and participative constraints. The managerial incentive plan is represented as $W=A+B X$; where $W$ is the agent's incentives, and $X$ represents the agent's performance which is measured by a quantifiable output, such as the profits, share price, productivity, etc. The parameter $A$ symbolizes the fixed component of the agent's remuneration, and $B$ symbolizes the amount of remuneration that is tied to the agent's performance $(X)$.

To simplify the integration of the managerial incentives constraint into the model, this study uses the simplest, yet accurate and informative accounting-based measure, namely net income, as the basis of the manager's compensation scheme. 
The measure is chosen due to its usefulness to shareholders in providing signals about the management's performance (Guidry et al. 1999; Scott 2015). This constraint is written as follows:

$$
\begin{aligned}
& X_{3 t} \\
& =a_{t} \\
& +\chi_{t} N I_{t}
\end{aligned}
$$

where $X_{3 t}$ : Total remuneration paid in period $\mathrm{t}$

$a_{t}$ : Fixed component of remuneration paid in period $t$

$\chi_{t}$ : Variable-compensation payout ratio in period $\mathrm{t}$

Furthermore, the principal should offer the agent the opportunity to generate incentives, at least as high as the agent's threshold, or as it is generally known, the participative constraint (Samuelson and Marks 2015). The incentives paid should not exceed the maximum payment that the shareholders can afford to pay to the managers without decreasing their efficiency level (Bryan et al. 2000). These constraints can be formulated as follows:

$X_{3}$

$\geq X_{3 \min (t)}$

$X_{3 t}$

$\leq \overline{X_{3 \max (t)}}$

Minimum dividend policy

Following the flow of funds in the NCI equation (refer to equation 12), $N C I_{t}$ represents the net cash inflow in period $t$ which is usually available to be added to the cash accounts $\left(\Delta X_{12 t}\right)$ and to be distributed as a dividend in period $t$ (Hamilton and Moses 1973; Morris and Daley 2009). To signal the managerial confidence in earnings growth and to meet the shareholders' expectations (Dickens et al. 2002; Arnott and Asness 2003), the financial model should accommodate the policy on minimum dividend to be paid to the shareholders. This policy constraint can be formulated as follows: 


$$
\begin{aligned}
& N C I_{t}-\Delta X_{12 t}-\delta_{t} N I_{t} \\
& \geq 0
\end{aligned}
$$

where $\delta_{t}$ is the dividend payout ratio at period t.

\section{Maximum dividend policy}

The company needs to ensure that it has sufficient retained earnings $\left(\Delta R P_{t}\right)$ available for reinvestment in the future and to pay dividends to the shareholders. Accordingly, the company's profit (i.e., $N I_{t}$ ) must be sufficient to fulfill both purposes during the accounting period(Lee et al. 2009; Damodaran 2013). This relationship can be expressed by a mathematical equation as follows:

$$
\begin{aligned}
& N I_{t} \\
& \geq d_{t} \\
& +\Delta R P_{t}
\end{aligned}
$$

\section{$\underline{\text { Financial performance constraints }}$}

One of the essential principles of financial management and governance mechanisms is ensuring that financial outcomes, as products of the accounting system, can be reliably used as the basis for formulating managerial remuneration. To achieve this goal, managers must maintain the profitability level as high as possible to ensure excellent performance and to secure a competitive position in the market (Ittner et al. 1997; Indjejikian 1999; Scott 2015). Therefore, the financial model needs to integrate a policy that limits the minimum profitability level (depicted by the Return on Equity (ROE)), which must not be less than the ROE of the profitability of the industry average (Rezaee 2011). Accordingly, this relationship can be mathematically written as follows:

$$
\begin{aligned}
& \frac{N I_{t}}{\text { Average total equity }} \\
& \quad \geq R O E_{\text {ind }(t)}
\end{aligned}
$$

\section{Operational efficiency constraint}

The efficiency ratio shows how efficiently a company performs its operational activities, as it measures how much of its income is spent on operating expenses (Rezaee 2011). To achieve an efficient level of operational activities, managers 
should maintain this ratio as low as possible, as a high-efficiency ratio indicates either high operating expenses or a low operational capability to generate income (Gardner et al. 2005). The company's efficiency ratio should be lower than, or equal to, the efficiency ratio of the industry average. This constraint is expressed as follows:

$$
\begin{gathered}
\frac{O p E x_{t}+X_{3 t}}{\left(\operatorname{IntInc}_{t}-\operatorname{IntEx_{t}}\right)+O \operatorname{Inc}_{t}} \times 100 \% \\
\leq E R_{\text {ind }(t)}
\end{gathered}
$$

Financial sustainability constraint

The most critical element of a bank's financial performance is its sustained revenue growth. Management is often under severe pressure to maintain a satisfactory interest margin to be able to survive industry competition. This creates the necessity for management to sustainably review all possible sources of revenue growth (Rezaee 2011). As this study is simulated through a case study of a bank and the purpose of the business model in banking is balance sheet management, the direct measure of revenue quality is Net Interest Income (NII). To satisfy long-term revenue growth, management should maintain the revenue during period $t$ at a level greater than or equal to the revenue in the previous period $(\mathrm{t}-1)$, or at least increase it by the minimum required revenue growth. Accordingly, the revenue growth constraint is formulated as:

$$
\begin{gathered}
N I I_{t}-\left(1+\varphi N I I_{t}\right) N I I_{t-1} \\
\geq 0
\end{gathered}
$$

c. Financial risk management and capital adequacy requirements

Liquidity risk: Balance sheet quality

As depository institutions, banks are commonly exposed to a liquidity risk which is caused by the unmatched maturity of their assets and liabilities. To insulate against this liquidity risk, balance sheet management is a necessity (Lange et al. 2013). Some ratios can be used to quantitatively assess the balance sheet's quality, including the loans ratio and the loan-to-deposit ratio (Rezaee 2011). 
The loans ratio shows the proportion of loans $\left(X_{11_{t}}\right)$ as a percentage of the total assets of the bank. This ratio indicates the extent to which assets are devoted to loans as opposed to other assets, including cash, securities, and property, plant and equipment. To preserve the high quality of assets and hence sustain its position in the industry, a bank should maintain its loans ratio within the optimal loans ratio, typically based on the historical data or the industry average, expressed as follows:

$$
\begin{aligned}
& L R_{t} \\
& \geq L R_{\min (t)} \\
& \quad \text { and } \\
& L R_{t} \\
& \leq \overline{L R_{\max }}
\end{aligned}
$$

Financial distress and bankruptcy risk

In corporate finance literature, financial distress is described as a condition where a company suffers a loss in its value that can be attributed to its deteriorating financial strength (Titman et al. 2014). To predict the probability of financial distress, positive asset growth can be used as an indicator of the success of a bank in protecting its future financial position and hence securing it from financial distress. Management should maintain long-term positive asset growth to secure the bank's financial position and hence avoid the risk of bankruptcy and strengthen the going-concern aspects of the company in the long term (Morris and Daley 2009). Accordingly, the total assets in period $\mathrm{t}\left(T A_{t}\right)$ must be greater than or equal to the minimum assets growth required in period t compared to the previous period $(\mathrm{t}-1)$. Therefore, the asset growth constraint for the model can be written as follows:

$$
\begin{gathered}
T A_{t}-\left(1+\varphi \text { Assets }_{t}\right) T A_{t-1} \\
\geq 0
\end{gathered}
$$

\section{Capital adequacy constraint}

Financial distress, bankruptcy, and other related costs are also strongly related to the leverage of a company (Altman and Hotchkiss 2006). Related to the concepts 
of corporate governance and risk management, the leverage ratio is significant for assessing the ability of a company to fulfill the interests of its stakeholders. For banks, capital is important to protect them against the risk of insolvency and financial failure. Capital absorbs unanticipated losses, with enough margin to ensure that the institution continues its operations as a going concern and hence protects its stakeholders' rights in the long term (BCBS 2011; Lange et al. 2013). To ensure that the developed model does not violate the regulation on the capital adequacy requirement, the model incorporates the minimum capital adequacy as a constraint. Adopting the regulatory framework imposed by the Basel Committee on Banking Supervision (BCBS), the capital adequacy requirement constraints are presented as follows:

Total regulatory capital

$\overline{\text { Total risk-adjusted } \text { assets }^{3}}$

$$
\geq 8.0 \%
$$

\section{Model Testing and Analysis Tool}

To address the issues of this study, the financial optimization problem is solved by using numerical data of a banking company, to obtain the best solutions that lead to the maximum value of the objective function, which is the value of shareholders' equity. The results of the model are then being compared with the original values based on the company's financial data to obtain the complete figure on how the developed model can provide different financial strategies for improving the company's value. Based on the results, the implications of agency concepts, as well as accounting and financial management practices integrated into the model are investigated in the most meaningful way to make an in-depth analysis of whether or not the integrated financial model can contribute towards improving the company's performance.

The financial model developed in this study is an optimization model which is solved using the Analytical Solver Platform v12.5 developed by Frontline Systems for

\footnotetext{
${ }^{3}$ Total risk-adjusted asset is calculated based on the elements determined by the BCBS.
} 
Microsoft. The Risk Solver Platform (RSP) provides a combination of optimization and simulation capabilities for model solving (Frontline 2013). This software has strong technical support for conventional optimization with its simplex LP solver engine, which can handle linear programming problems with up to 2,000 variables and 2,000 constraints. The software includes five built-in algorithms for solving the full spectrum of an optimization model. As the present model is a linear programming model, the RSP adopted in this study solves the model using an enhanced version of the simplex method.

\section{Results and Discussion}

\section{Optimal value and book value of share price}

The objective of this study is to investigate to what extent the developed model, based on agency relationships and financial accounting practices, can increase a company's value and mitigate the agency problems. To generally conclude the result of this study, the comparison between the values per share of equity resulting from the model's results and the book value of the share price based on the financial reports are discussed.

Based on Table 1, the value per share of equity based on the financial statements, or the book value per share of equity, which is calculated by using the formula in equation (1), is 38.3138 . This value is lower than the optimal value per share of equity achieved from the proposed financial model. Based on the results of the developed model, the optimal dividend paid to shareholders resulting from the optimization procedure achieves a value in the range from $2,412.86$ to $4,536.62$, with an average value of $3,729.28$. These results are significantly higher than the actual dividend paid to the shareholders based on the historical data from the annual reports which vary from $1,738.35$ to $3,211.71$, with an average of 2,722.58 during the observation period. Therefore, the present value of the dividend, which reflects the achieved optimal value per share of equity is also higher, with a value of 41.9138 . This result implies that the

proposed financial model has succeeded in improving the value of the company, which is reflected in its value per share of equity. 
Table 1.

The Optimal Results of Model Testing

\begin{tabular}{|c|c|c|}
\hline & Proposed FM & Baseline \\
\hline Objective Value & 41.9138 & 38.3138 \\
\hline Value $\mathrm{d}_{1}$ & $2,412.86$ & $1,738.35$ \\
\hline Value $\mathrm{d}_{2}$ & $3,571.03$ & $2,621.55$ \\
\hline Value $\mathrm{d}_{3}$ & $3,963.84$ & $2,918.27$ \\
\hline Value $\mathrm{d}_{4}$ & $4,162.04$ & $3,123.00$ \\
\hline Value $\mathrm{d}_{5}$ & $4,536.62$ & $3,211.71$ \\
\hline Value $X_{11_{1}}$ & $436,143.25$ & $466,631.00$ \\
\hline Value $X_{11_{2}}$ & $542,633.57$ & $493,459.00$ \\
\hline Value $X_{11_{3}}$ & $586,457.45$ & $500,057.00$ \\
\hline Value $X_{11_{4}}$ & $723,700.54$ & $525,682.00$ \\
\hline Value $X_{11_{5}}$ & $815,259.01$ & $556,648.00$ \\
\hline Value $X_{12_{1}}$ & $9,843.29$ & $11,340.00$ \\
\hline Value $X_{12_{2}}$ & $12,303.22$ & $10,119.00$ \\
\hline Value $X_{12_{3}}$ & $25,887.50$ & $13,241.00$ \\
\hline Value $X_{124}$ & $27,836.83$ & $19,666.00$ \\
\hline Value $X_{125}$ & $52,646.43$ & $20,634.00$ \\
\hline Value $X_{13_{1}}$ & $8,886.44$ & $14,421.00$ \\
\hline Value $X_{13_{2}}$ & $9,257.89$ & $10,072.00$ \\
\hline Value $X_{13_{3}}$ & $47,325.87$ & $10,393.00$ \\
\hline Value $X_{13_{4}}$ & $50,889.50$ & $10,886.00$ \\
\hline Value $X_{13_{5}}$ & $53,367.82$ & $7,744.00$ \\
\hline Value $X_{14_{1}}$ & $163,111.89$ & $49,629.00$ \\
\hline Value $X_{14_{2}}$ & $169,929.97$ & $57,910.00$ \\
\hline Value $X_{14_{3}}$ & $176,070.31$ & $68,176.00$ \\
\hline Value $X_{144}$ & $245,172.52$ & $77,521.00$ \\
\hline
\end{tabular}


The Indonesian Journal of Accounting Research - Jan, Vol. 20, No.1 , 2017

\begin{tabular}{|c|c|c|}
\hline Value $X_{14_{5}}$ & $257,112.42$ & $82,406.00$ \\
\hline Value $X_{21_{1}}$ & $277,845.11$ & $368,721.00$ \\
\hline Value $X_{21_{2}}$ & $335,417.40$ & $374,663.00$ \\
\hline Value $X_{21_{3}}$ & $417,314.13$ & $401,147.00$ \\
\hline Value $X_{21_{4}}$ & $451,017.03$ & $437,655.00$ \\
\hline Value $X_{21_{5}}$ & $556,564.28$ & $459,429.00$ \\
\hline Value $X_{22_{1}}$ & $162,511.21$ & $15,109.00$ \\
\hline Value $X_{22_{2}}$ & $172,261.88$ & $12,608.00$ \\
\hline Value $X_{22_{3}}$ & $175,707.12$ & $15,899.00$ \\
\hline Value $X_{224}$ & $189,763.69$ & $22,126.00$ \\
\hline Value $X_{225}$ & $201,149.51$ & $25,922.00$ \\
\hline Value $X_{23_{1}}$ & $97,507.64$ & $101,819.00$ \\
\hline Value $X_{23_{2}}$ & $101,607.76$ & $130,210.00$ \\
\hline Value $X_{23_{3}}$ & $107,701.99$ & $118,652.00$ \\
\hline Value $X_{23_{4}}$ & $106,857.55$ & $124,712.00$ \\
\hline Value $X_{23_{5}}$ & $106,908.42$ & $132,808.00$ \\
\hline Value $X_{24_{1}}$ & $15,142.29$ & $12,039.00$ \\
\hline Value $X_{24_{2}}$ & $36,783.05$ & $13,513.00$ \\
\hline Value $X_{24_{3}}$ & $37,518.72$ & $11,561.00$ \\
\hline Value $X_{244}$ & $40,520.21$ & $10,022.00$ \\
\hline Value $X_{245}$ & $42,951.43$ & $9,687.00$ \\
\hline Value $X_{3_{1}}$ & 58.00 & 58.00 \\
\hline Value $X_{3_{2}}$ & 68.00 & 68.00 \\
\hline Value $X_{3_{3}}$ & 80.00 & 71.00 \\
\hline Value $X_{34}$ & 78.44 & 55.00 \\
\hline Value $X_{35}$ & 78.93 & 50.00 \\
\hline
\end{tabular}


The results of the proposed financial model are found to be the most optimal business strategy that can increase the value for the shareholders. According to the summary of outcomes depicted in Table 2, the proposed financial model suggests that the company should have a higher ratio of FBI than the current business model. As explained in the model specification above, the net interest income growth constraint is incorporated in the model to ensure that the company maintains the sustainability of all the possible sources of its interest income while performing other banking activities. Accordingly, as the model is developed within the optimization framework, the optimal ratio of FBI is generated from the best combination of various financial activities, i.e., interestincome-related and non-interest-related activities, which can maximize the value for the shareholders(Beck et al. 2013).

In addition to the FBI ratio, the fragility of a bank can also be reduced by making loans that are financed relatively heavily by deposits which are not prematurely withdrawn (Song and Thakor 2007). The effectiveness of this strategy can be determined by maintaining the proportion of loans to deposits, which is reflected in the Loans-to-Deposits Ratio (LTDR). The results generally show that the developed model proposes a higher proportion of loans-to-deposits (between 1.4053 and 1.6178) to preserve the funding requirement for safeguarding the deposits earned from customers and, on the other hand, securing the loans made by a bank. The results of the proposed model reflect the optimal liquidity management policy of a bank, as it provides the optimal composition of loans and deposits that reduces potential agency problems among stakeholders, particularly investors, customers, and depositors (Koch and MacDonald 2006; Mullineux 2006; Lange et al. 2013).

Furthermore, the management should preserve the high quality of the assets to maintain operational efficiency and secure their bank's position in the industry. Accordingly, the Loans Ratio (LR) constraints are incorporated into the model to ensure that the bank's loan ratio lies within the optimal range of the minimum assets' profitability and the maximum loans allowed, to avoid any liquidity problems (Rezaee 2011). Table 2 depicts that, to maintain its operational efficiency and profitability, the loans proportion of the total earnings assets should be reduced within the optimal 
range suggested by the proposed financial model. This is shown by the lower level of LR resulting from the financial model, compared to the actual LR based on the financial statements. This result implies that the management is required to uphold the LR at a minimum of $62.54 \%$ and a maximum of $66.96 \%$ (suggested by the proposed model) to protect their company's financial position from liquidity risk exposure and hence preserving their company's financial stability in the future.

The optimal business combination and improved organizational efficiency discussed above can lead to higher profitability levels. This is indicated by the generally higher value of Net Income (NI), Net Interest Income (NII), Net Interest Margin (NIM) and Return on Equity (ROE) resulting from the proposed financial models. The successfulness of the company in maintaining its financial strength through the proposed financial models is also shown by the generally higher value of the Return on Assets (ROA) and the Capital Adequacy Ratio (CAR) produced by the proposed financial model as depicted in Table 2. This suggests that the optimal proportion of LR and the FBI in the operating activities proposed by the developed financial model can help the management to improve the efficiency of operational activities by diversifying risk onto more controlled interest-earning assets. Furthermore, the result also suggests that from the business strategy proposed by the model, the company can maintain its capital adequacy to absorb unanticipated losses from liquidity risks and ensure the sustainability of its financial strength (Mulbert 2013).

\section{Agency theory implications}

The financial model developed in this study emphasizes on the benefit of integrating sound accounting system into financial strategies within a framework of agency theory. The focus of this study is investigating the way the integrated model can strengthen the financial position and hence improve the financial performance reflected in the company value. Based on the model testing, the results show that the proposed model can generally improve the financial performance, as discussed above and provide confidence for the existing and potential investors in making their 
economic decisions (Aretz and Bartram 2010; Brown et al. 2011). This implies that the financial model developed in this study can improve the informational content of the accounting outcomes provided for users, including shareholders, creditors, and depositors; thus, it can signal a company's excellent reputation in the market. In this way, the financial model can be used to reduce the agency problems that may arise from the information asymmetry by providing more reliable accounting information as a basis for making economic decisions.

Furthermore, Table 2 depicts that the financial model produces lower agency costs than the existing condition of the company, hence succeeds in mitigating the agency problems. This argument is supported by results of model testing, particularly in the improvement in the management's efficiency in utilizing the assets entrusted by the investors, which is shown by higher Earnings-to-Assets (ETA) and. Moreover, the Table also shows that the company produce higher Free Cash Flow to Equity (FCFE), as well as higher level of dividend that should be paid for shareholders (with a range of $2,412.86$ to $4,536.62$ ), compared to the original dividend policy of the company (with a range of $1,738.35$ to $3,211.71$ ). The increase in the dividend level is also accompanied by the increase of incentives level to be paid to the executives $\left(X_{3}\right)$, as shown in Table 1. These results strongly indicate that the proposed financial model can align the interest of shareholders and management, by motivating the managers to take more actions to improve the company's performance; hence this can increase the managers' rewards and maximize the shareholders' wealth at the same time (Jensen and Murphy 1990). 
Table 2. The Comparison of the Optimal Financial Outcomes

Optimal Results of the Financial Model

\begin{tabular}{|c|c|c|c|c|c|c|c|c|c|c|c|c|c|}
\hline \multirow[b]{2}{*}{ Year } & \multicolumn{2}{|c|}{ Business Model } & \multicolumn{3}{|c|}{ Shareholders' Interest } & \multirow[b]{2}{*}{ CIR } & \multicolumn{3}{|c|}{ Profitability } & \multicolumn{4}{|c|}{ Stability and Risk Management } \\
\hline & FBI & LTDR & FCFE & ETA & Dividend & & NII & NIM & ROE & $\begin{array}{c}\text { Earning } \\
\text { Assets }\end{array}$ & CAR & ROA & $\mathbf{L R}$ \\
\hline 1 & 0.8612 & 1.5697 & $5,138.37$ & 0.0201 & $2,412.86$ & 0.1774 & $14,317.13$ & 0.0278 & 0.1567 & $515,208.44$ & 0.1386 & 0.0114 & 0.6254 \\
\hline 2 & 0.8457 & 1.6178 & $11,522.10$ & 0.0159 & $3,571.03$ & 0.2267 & $16,757.69$ & 0.0248 & 0.1777 & $676,054.76$ & 0.1555 & 0.0100 & 0.6696 \\
\hline 3 & 0.8787 & 1.4053 & $10,957.85$ & 0.0162 & $3,963.84$ & 0.1906 & $19,447.14$ & 0.0248 & 0.2256 & $784,932.89$ & 0.1559 & 0.0118 & 0.6420 \\
\hline 4 & 0.8906 & 1.6046 & $5,655.70$ & 0.0129 & $4,162.04$ & 0.1843 & $23,833.72$ & 0.0253 & 0.2500 & $941,670.25$ & 0.1715 & 0.0124 & 0.6382 \\
\hline 5 & 0.8815 & 1.4648 & $34,733.24$ & 0.0116 & $4,536.62$ & 0.1598 & $21,791.97$ & 0.0196 & 0.2280 & $1,112,992.53$ & 0.1577 & 0.0110 & 0.6434 \\
\hline Ave. & \begin{tabular}{|l}
0.8715 \\
\end{tabular} & 1.5324 & $13,601.45$ & 0.0153 & $3,729.28$ & 0.1878 & $19,229.53$ & 0.0244 & 0.2076 & $806,171.77$ & 0.1558 & 0.0113 & 0.6437 \\
\hline
\end{tabular}


Book Value Based on Financial Statement

\begin{tabular}{|c|c|c|c|c|c|c|c|c|c|c|c|c|c|}
\hline \multirow[b]{2}{*}{ Year } & \multicolumn{2}{|c|}{ Business Model } & \multicolumn{3}{|c|}{ Shareholders' Interest } & \multirow[b]{2}{*}{ CIR } & \multicolumn{3}{|c|}{ Profitability } & \multicolumn{4}{|c|}{ Stability and Risk Management } \\
\hline & FBI & LTDR & FCFE & ETA & Dividend & & NII & NIM & ROE & $\begin{array}{c}\text { Earning } \\
\text { Assets }\end{array}$ & CAR & ROA & LR \\
\hline 1 & 0.8362 & 1.2655 & -79.00 & 0.0126 & $1,738.35$ & 0.2108 & $10,301.00$ & 0.0216 & 0.1651 & $476,703.00$ & 0.0807 & 0.0086 & 0.7522 \\
\hline 2 & 0.8139 & 1.3171 & $2,731.00$ & 0.0125 & $2,621.55$ & 0.2202 & $11,922.00$ & 0.0215 & 0.1695 & $555,522.00$ & 0.0915 & 0.0090 & 0.7635 \\
\hline 3 & 0.8460 & 1.2466 & $3,011.00$ & 0.0115 & $2,918.27$ & 0.2055 & $12,607.00$ & 0.0217 & 0.1760 & $580,112.50$ & 0.1001 & 0.0098 & 0.7487 \\
\hline 4 & 0.8405 & 1.2011 & $5,612.00$ & 0.0114 & $3,123.00$ & 0.2050 & $13,122.00$ & 0.0215 & 0.1802 & $611,006.00$ & 0.1001 & 0.0103 & 0.7319 \\
\hline 5 & 0.8201 & 1.2116 & -837.00 & 0.0117 & $3,211.71$ & 0.2285 & $13,934.00$ & 0.0215 & 0.1767 & $648,504.00$ & 0.1024 & 0.0105 & 0.7384 \\
\hline Ave. & 0.8313 & 1.2484 & $2,087.60$ & 0.0119 & $2,722.58$ & 0.2140 & $12,377.20$ & 0.0216 & 0.1735 & $574,369.50$ & 0.0950 & 0.0096 & 0.7469 \\
\hline
\end{tabular}




\section{Plausibility of the Results and Generalization of the Model}

\section{Validation of the Model}

The financial model developed and presented in this study is thoroughly examined by some rigorous, structured validation procedures. The results of the model testing are being validated through two steps, i.e., validation experiments and validation test, to ensure that the model's solutions have reasonably reflected the real outcomes (McCarl and Spreen 2011), as discussed below.

a. Validation experiments: prediction experiment. This type of experiment is the common validation test performed in the previous mathematical programming research, such as Barnett et al. (1982) and Brink and McCarl (1979). In this test, the model is examined to see whether or not the results are close enough to the real observed outcomes. Based on the observation, several key performance indicators resulting from the developed financial model exist between the minimum and maximum values of the actual performance indicators of the observed company. Moreover, other indicators which fall outside the minimum and maximum range are still within the standard deviation of the value of actual outcomes. The summary of the predictive experiment is shown in Table 3.

b. Validation test: association test. A further step in the model's validation is performing an association test, to examine the degree of correspondence between the achieved outcomes from the model's solutions and the actual outcomes. This test is essential to ensure that the set of results from the model are plausible and similar to the observed actual outcomes so that the developed financial model can be generalized(McCall and Spreen 2011). Following the study by Beck, this study applied a regression technique to measure the association of the outcomes with the observed values. The regression test result is depicted in Table 4. Based on the table, the values resulting from the association test indicate a strong association between the model's results and the observed values, i.e., close to 0 for the intercept and close to 1 for the slope (McCarl and Spreen 2011). Thus, the developed model can be justified as a valid model.

Based on these procedures, the model satisfies all the assertions necessary to satisfy the validation requirements. Moreover, based on the predictive experiments (Table 3) and the association test (Table 4), the model is numerically valid and reasonably reflects the real outcomes of the observed object. Therefore, the results of the model can be considered to be plausible, and the outcomes are valid, and hence the model can be used as a sound basis for the decision-making process. 
Table 3.

Summary of the Predictive Experiment Results

\begin{tabular}{|c|c|c|c|c|c|c|}
\hline \multirow{2}{*}{$\begin{array}{l}\text { Financial } \\
\text { Indicators }\end{array}$} & \multicolumn{5}{|c|}{ Company Statistical Figure* } & \multirow{2}{*}{$\begin{array}{l}\text { Results of } \\
\text { Model }\end{array}$} \\
\hline & Minimum & Maximum & Mean & Variance & Std. Dev & \\
\hline FBI & 0.7234 & 0.8460 & 0.8056 & 0.0012 & 0.0349 & 0.8715 \\
\hline LTDR & 1.1606 & 1.4962 & 1.2898 & 0.0130 & 0.1139 & 1.5324 \\
\hline $\mathrm{OHC}$ & 0.0128 & 0.0204 & 0.0145 & 0.0000 & 0.0026 & 0.0110 \\
\hline CIR & 0.2050 & 0.3402 & 0.2340 & 0.0015 & 0.0383 & 0.1878 \\
\hline ROE & 0.1148 & 0.1953 & 0.1715 & 0.0004 & 0.0212 & 0.2076 \\
\hline$\overline{\text { NIM }}$ & 0.0215 & 0.0246 & 0.0222 & 0.0000 & 0.0011 & 0.0244 \\
\hline $\mathrm{ROA}$ & 0.0084 & 0.0113 & 0.0102 & 0.0000 & 0.0010 & 0.0113 \\
\hline Loans ratio & 0.6189 & 0.7635 & 0.7221 & 0.0017 & 0.0411 & 0.6437 \\
\hline CET 1 ratio & 0.0000 & 0.0820 & 0.0461 & 0.0017 & 0.0415 & 0.1181 \\
\hline Tier 1 ratio & 0.0714 & 0.1024 & 0.0896 & 0.0002 & 0.0150 & 0.1393 \\
\hline Total capital ratio & 0.0966 & 0.1170 & 0.1095 & 0.0001 & 0.0099 & 0.1558 \\
\hline ATO & 0.0166 & 0.0189 & 0.0183 & 0.0000 & 0.0008 & 0.0103 \\
\hline$\overline{\text { ETA }}$ & 0.0114 & 0.0126 & 0.0119 & 0.0000 & 0.0005 & 0.0153 \\
\hline
\end{tabular}

* Based on 10-years historical data

Table 4.

Summary of the Association Test between Results and Actual Data

\begin{tabular}{|l|l|}
\hline Intercept & Slope \\
\hline-0.006958953 & 0.97650748 \\
\hline
\end{tabular}

\section{Generalization of the Model}

This study has developed a new financial optimization model embedding some crucial issues in business to formulate a set of appropriate financial strategies, which is based on the general principles of corporate finance and accounting. The specified objective function and constraints of the model are based on the Generally Accepted Accounting Principles (GAAP) and reflect the interrelationship of accounts presented in a company's financial reports. The constraints are specified by following the general theories of accounting and finance. The objective function of the model is depicted by the maximization of equity value through a Discounted Cash Flow (DCF) model using Dividend per Share (DPS) as the proxy for the cash flow paid to equity holders. The applicability of the cost of equity is calculated through the Capital Asset Pricing Model (CAPM), as the discounting factors in the model reflect the real economic and market risks faced by the company and hence represent business reality. The 
constraints of the model also incorporate relevant regulations as imposed by the global regulatory bodies. Hence the financial model proposed in this study can be implemented by other companies globally. Furthermore, this study is conducted through structured stages, hence the modeling approach adopted in this study can provide a powerful method to achieve the objective of the financial modeling. Moreover, the financial model proposed in this study is also simulated and tested through a numerical application, based on a real case study approach, to examine the applicability of the model in a real-life business problem. Therefore, the modeling approach proposed by this study can be justified as a sufficient and an appropriate approach to be adopted by other companies.

\section{Conclusion}

This paper proposes a corporate financial model for formulating financial strategies in a banking company within the framework of agency theory and accounting information system. This study constructs the model as a prescriptive financial optimization problem of the corporate financial management via the organizational design framework. The model is used to study the relationships between agency theory, information asymmetry, accounting information, and company value. The model specifies the objective function as maximizing the shareholders' value, subject to a set of constraints representing the managers and other stakeholders' interests. This study simulates the model with a numerical implementation that shows how the integrated financial model can propose optimal financial strategies to ensure efficient financial management, mitigate agency problems and improve the company's value. The developed model is operational as it satisfies some validation tests and provides plausible results and implications.

While the proposed financial model is a contribution to multidisciplinary literature, it emphasizes numerous opportunities for future research. Possible extensions to the model include (but are not limited to): 1) integrating the wide-spectrum risks on banks; 2) integrating other contemporary issues in accounting and finance, such as fair value accounting, disclosure and risk management; 3) forming constraints based on asset-liability management, cf. Kosmidou and Zopounidis (2004); 4) replacing other proxies for the objective functions rather than maximizing the value per share of equity, and 5) shifting the model into a stochastic model to accommodate the uncertainty issue in business. The model is sufficiently flexible to be adapted to other strategic policies regarding the interests of decision makers.

\section{References}

Altman, E. I., and E. Hotchkiss. 2006. Corporate Financial Distress and Bankruptcy: Predict and Avoid Bankruptcy, Analyze and Invest in Distressed Debt. 3rd ed. Hoboken, N.J.: Wiley. 
Aretz, K., and S. M. Bartram. 2010. Corporate hedging and shareholder value. Journal of Financial Research 33 (4):317-371.

Arnott, R. D., and C. S. Asness. 2003. Surprise! Higher dividends = higher earnings growth. Financial Analysts Journal 59 (1):70-87.

Barnett, D., B. Blake, and B. A. McCarl. 1982. Goal programming via multidimensional scaling applied to Senegalese subsistence farms. American Journal of Agricultural Economics 64 (4):720-727.

BCBS. 2011. Basel III: A Global Regulatory Framework for More Resilient Banks and Banking Systems. Switzerland: Bank for International Settlements.

Beck, T., A. Demirgüç-Kunt, and O. Merrouche. 2013. Islamic vs. conventional banking: Business model, efficiency and stability. Journal of Banking and Finance 37 (2):433-447.

Berle, A. A., G. C. Means, and S. H. William. 1932. The Modern Corporation and Private Property. New York: Macmillan Co.

Birge, J. R., and P. Júdice. 2013. Long-term bank balance sheet management: Estimation and simulation of risk-factors. Journal of Banking and Finance 37 (12):4711-4720.

Brealey, R. A., S. C. Myers, and F. Allen. 2016. Principles of Corporate Finance. 12th ed. New York: McGraw-Hill Irwin.

Brink, L., and B. McCarl. 1979. The adequacy of a crop planning model for determining income, income change, and crop mix. Canadian Journal of Agricultural Economics 27 (3):13-25.

Brodt, A. I. 1978. A dynamic balance sheet management model for a Canadian chartered bank. Journal of Banking and Finance 2 (3):221-241.

Brown, P., W. Beekes, and P. Verhoeven. 2011. Corporate governance, accounting, and finance: A review. Accounting and Finance 51:96-173.

Bryan, S., L. Hwang, and S. Lilien. 2000. CEO stock-based compensation: An empirical analysis of incentive-intensity, relative mix, and economic determinants. The Journal of Business 73 (4):661693.

Carleton, W. T., C. L. Dick, Jr., and D. H. Downes. 1973. Financial policy models: Theory and practice. The Journal of Financial and Quantitative Analysis 8 (5):691-709.

Chakroun, F., and F. Abid. 2013. A multiobjective model for bank asset liability management: The case of a Tunisian bank. IUP Journal of Financial Risk Management 10 (4):35-56.

Chambers, D., and A. Charnes. 1961. Inter-temporal analysis and optimization of bank portfolios. Management Science 7 (4):393-410.

Chi, G. T., H. C. Dong, and X. Y. Sun. 2007. Decision-making model of bank's assets portfolio based on multi-period dynamic optimization. Systems Engineering - Theory and Practice Online 27 (2):1-16.

Cohen, K. J., and F. S. Hammer. 1967. Linear programming and optimal bank asset management decisions. The Journal of Finance 22 (2):147-165.

Copeland, T. E., J. F. Weston, and K. Shastri. 2005. Financial Theory and Corporate Policy. 4th ed. Boston, MA: Addison-Wesley.

Crane, D. B. 1971. A stochastic programming model for commercial bank bond portfolio management. The Journal of Financial and Quantitative Analysis 6 (3):955-976. 
Damodaran, A. 2013. Valuing financial service firms. Journal of Financial Perspectives 1 (1):59-74.

Demski, J. S. 2008. Managerial Uses of Accounting Information. Vol. 4. New York: Springer.

Dickens, R. N., K. M. Casey, and J. A. Newman. 2002. Bank dividend policy: Explanatory factors. Quarterly Journal of Business and Economics 41 (1/2):3-12.

Douma, S. W., and H. Schreuder. 2008. Economic Approaches to Organizations. 4th ed. Harlow, England; New York: Financial Times/Prentice Hall.

Drever, M., P. A. Stanton, and S. McGowan. 2007. Contemporary Issues in Accounting. Milton, Qld: John Wiley \& Sons Australia.

Eisenhardt, K. M. 1989. Agency theory: An assessment and review. The Academy of Management Review 14 (1):57-74.

Frontline. 2013. Frontline Solver Version 12.5 User Guide. Nevada: Frontline Systems, Inc.

Gardner, M. J., D. L. Mills, and E. S. Cooperman. 2005. Managing Financial Institutions. London: SouthWestern.

Gershefski, G. W. 1969. Building a corporate financial model. Harvard Business Review 47 (4):61-72.

Guidry, F., A. J. Leone, and S. Rock. 1999. Earnings-based bonus plans and earnings management by business-unit managers. Journal of Accounting and Economics 26 (1-3):113-142.

Güven, S., and E. Persentili. 1997. A linear programming model for bank balance sheet management. Omega 25 (4):449-459.

Hamilton, W. F., and M. A. Moses. 1973. An optimization model for corporate financial planning. Operations Research 21 (3):677-692.

Ho, T. S. Y., and S. B. Lee. 2004. The Oxford Guide to Financial Modeling: Applications for Capital Markets, Corporate Finance, Risk Management, and Financial Institutions. Oxford: Oxford University Press.

Holmstrom, B. 1979. Moral hazard and observability. Bell Journal of Economics 10 (1):74-91.

Holmstrom, B. R., and J. Tirole. 1989. The theory of the firm. In Handbook of Industrial Organization, edited by R. Schmalensee and R. D. Willig. Amsterdam: Elsevier Science Publishers B. V., 61-133.

Ijiri, Y., F. K. Levy, and R. C. Lyon. 1963. A linear programming model for budgeting and financial planning. Journal of Accounting Research 1 (2):198-212.

Indjejikian, R. J. 1999. Performance evaluation and compensation research: An agency perspective. Accounting Horizons 13 (2):147-157.

Ittner, C. D., D. F. Larcker, and M. V. Rajan. 1997. The choice of performance measures in annual bonus contracts. The Accounting Review 72 (2):231-255.

Jedicke, V., W. L. Wilbur, and A. K. Rifai. 1994. Goal programming: An effective tool in commercial bank management. American Journal of Business 9 (1):31.

Jensen, M. C., and W. H. Meckling. 1976. Theory of the firm: Managerial behaviour, agency cost, and ownership structure. Journal of Financial Economics 3 (4):305-360.

Jensen, M. C., and K. J. Murphy. 1990. Performance pay and top management incentives. Journal of Political Economy 98 (2):225-264. 
Kanodia, C. 2014. Game theory models in accounting. In Game Theory and Business Applications, edited by K. Chatterjee and W. Samuelson. New York: Springer Science+Business Media, 43-79.

Khan, H. 2015. Optimal incentives for takaful (Islamic insurance) operators. Journal of Economic Behavior and Organization 109:135-144.

Koch, T. W., and S. S. MacDonald. 2006. Bank Management. Mason, Ohio: Thomson Higher Education.

Koo, D. 1977. Elements of Optimization: With applications in Economics and Business. New York: Springer-Verlag.

Korhonen, A. 2001. Strategic financial management in a multinational financial conglomerate: A multiple goal stochastic programming approach. European Journal of Operational Research 128 (2):418-434.

Kosmidou, K., and C. Zopounidis. 2004. Combining a goal programming model with simulation analysis for bank asset liability management. INFOR 42 (3):175-187.

Lange, H. P., A. Saunders, and M. M. Cornett. 2013. Financial Institutions Management. 3rd ed. North Ryde, N.S.W: McGraw-Hill Australia.

Langen, D. 1989. A multi-objective decision model for bank asset/liability management. Mathematical and Computer Modelling 12 (10):1419-1435.

Lee, A. C., C. F. Lee, and J. C. Lee. 2009. Financial Analysis, Planning and Forecasting: Theory and Application. Singapore: World Scientific.

McCarl, B. A., and T. H. Spreen. 2011. Applied Mathematical Programming Using Algebraic Systems. Texas, TX: Texas A\&M University, College Station.

McGuigan, J. R., R. C. Moyer, and F. H. Harris. 2014. Managerial Economics: Applications, Strategy, and Tactics. 13th ed. Stamford, CT, USA: Cengage Learning.

Morris, J. R., and J. P. Daley. 2009. Introduction to Financial Models for Management and Planning. Boca Raton: CRC Press.

Moss, C. B. 2010. Risk, Uncertainty, and the Agricultural Firm. Singapore: World Scientific Publishing Company.

Mulbert, P. O. 2013. Corporate Governance of Banks. In Risk Management and Corporate Governance, edited by A. Jalilvand and A. G. Malliaris. Hoboken, N.J.: Taylor and Francis.

Mullineux, A. 2006. The corporate governance of banks. Journal of Financial Regulation and Compliance 14 (4):375-382.

Nuryanah, S., and S. M. N. Islam. 2015. Corporate Governance and Financial Management: Computational Optimisation Modelling and Accounting Perspectives. United Kingdom: Palgrave Macmillan.

Rethel, L., and T. J. Sinclair. 2012. The Problem with Banks. New York: Zed Books.

Rezaee, Z. 2011. Financial Services Firms: Governance, Regulations, Valuations, Mergers, and Acquisitions. Hoboken, N.J: Wiley-Blackwell.

Samuelson, W., and S. G. Marks. 2015. Managerial Economics. 8th ed. Hoboken, NJ: John Wiley \& Sons, Inc.

Schroeck, G. 2002. Risk Management and Value Creation in Financial Institutions. edited by G. Schroeck. U.S.: Wiley. 
Scott, W. R. 2015. Financial Accounting Theory. 7th ed. Toronto, Ontario Pearson Canada.

Song, F., and A. V. Thakor. 2007. Relationship banking, fragility, and the asset-liability matching problem. Review of Financial Studies 20 (6):2129-2177.

Stern, J. M. 1972. The Dynamics of Financial Planning. In Applications of Management Science in Banking and Finance, edited by S. Eilon and T. R. Fowkes. Essex: Gower Press, 25-48.

Subramanyam, K. R., and J. J. Wild. 2014. Financial Statement Analysis. 11th ed. Boston: McGraw-Hill Irwin.

Tirole, J. 2001. Corporate Governance. Econometrica 69 (1):1-35.

Titman, S., A. J. Keown, and J. D. Martin. 2014. Financial Management: Principles and Applications. Upper Saddle River: Pearson.

Van Greuning, H., and S. B. Bratanovic. 2009. Analyzing Banking Risk: A Framework for Assessing Corporate Governance and Risk Management. Washington, DC: World Bank.

Van Horne, J. C., and J. M. Wachowicz. 2005. Fundamentals of Financial Management. Harlow, Essex, England: FT Prentice-Hall.

Williams, H. P. 2013. Model Building in Mathematical Programming. Fifth ed. United Kingdom: John Wiley \& Sons, Ltd.

Zenios, S. A. 2007. Practical Financial Optimization: Decision Making for Financial Engineers. Malden, MA: Blackwell Pub.

\section{APPENDIX 1. LIST OF VARIABLES AND PARAMETERS}

\section{Unknown Variables}

\section{A. Independent variables of the objective function}

$d_{t} \quad$ : Dividend paid in period $\mathrm{t}$

B. Constraint variables

1) $X_{11 t} \quad$ : Loans, bills discounted and other receivables in period $\mathrm{t}$

2) $X_{12 t}:$ Cash and liquid assets in period $t$

3) $X_{13} t \quad$ : Receivables due from other financial institutions in period $\mathrm{t}$

4) $X_{14 t}:$ Securities in period $\mathrm{t}$

5) $X_{21 t} \quad$ : Deposits and other public borrowings in period $\mathrm{t}$

6) $X_{22} \quad$ : Payables due to other financial institutions in period $t$

7) $X_{23 t} \quad$ : Debt issues in period $\mathrm{t}$

8) $\quad X_{24 t} \quad$ : Loan capital in period $\mathrm{t}$

9) $X_{3 t} \quad$ : Remuneration paid for executives in period $\mathrm{t}$

\section{Parameters provided by management}

\section{A. Accounting parameters}

1) $\quad \mathrm{NI}_{t} \quad$ Net income in period $\mathrm{t}$ 
2) IntInc $_{t} \quad:$ Interest income in period $\mathrm{t}$

3) IntEx $\quad$ : Interest expenses in period $\mathrm{t}$

4) OInc $\quad$ : Other operating income in period $t$

5) $\quad \operatorname{ImpEx}_{t}:$ Impairment expenses in period $\mathrm{t}$

6) $O p E x_{t} \quad$ Operating expenses, other than remuneration expense, in period $\mathrm{t}$

7) $\operatorname{CTax}_{t} \quad$ : Corporate tax in period $\mathrm{t}$

8) PTax $_{t}$ : Policyholder tax in period $\mathrm{t}$

9) NonIA $A_{t}$ : Total non-interest earnings assets in period $\mathrm{t}$

10) NonIL $L_{t}$ : Total non-interest bearing liabilities in period $\mathrm{t}$

11) $S C_{t} \quad:$ Share capital in period $t$

12) $\operatorname{Res}_{t} \quad:$ Reserves in period $\mathrm{t}$

13) $R P_{t} \quad:$ Retained profit in period $\mathrm{t}$

14) $\Delta R P_{t} \quad:$ The change of retained profit in year $\mathrm{t}$

15) $\mathrm{NCI}_{t} \quad$ : Net cash inflows in period $\mathrm{t}$

16) $\mathrm{CFO}_{t} \quad$ : Net cash flow from operating activities in period $\mathrm{t}$

17) $C \mathrm{CI}_{t} \quad$ : Net cash flow from investing activities in period $\mathrm{t}$

18) $C F F_{t} \quad$ : Net cash flow from financing activities in period $t$

19) $P P E_{t} \quad:$ Property, plant, and equipment in period $\mathrm{t}$

20) IntAs $s_{t}$ : Intangible assets in period $\mathrm{t}$

21) $C A D_{t} \quad$ : Cash available for dividends in period $\mathrm{t}$

22) $R O E_{t} \quad:$ Return on equity in period $t$

23) $\quad$ NIM $\quad$ : Net interest margin in period $\mathrm{t}$

24) $E R_{t} \quad:$ Efficiency ratio in period $\mathrm{t}$

25) $\mathrm{NII}_{t} \quad:$ Net interest income in period $\mathrm{t}$

26) $L R_{t} \quad:$ Loans ratio in period $\mathrm{t}$

27) $L T D R_{t} \quad:$ Loans to deposits ratio in period $\mathrm{t}$

28) $T A_{t} \quad:$ The total assets in period $\mathrm{t}$

29) $\mathrm{AccOCI}_{t}$ : Accumulated other comprehensive income in period $\mathrm{t}$

B. Financial parameters and definition
1) $k_{e}$
: Cost of equity capital
2) $g$
: The constant growth rate in perpetuity expected for the dividends
3) $\delta_{t}$
: The dividend payout ratio in period $t$
4) $a_{t} \quad:$ Fixed component of the remuneration paid in period $\mathrm{t}$
5) $\chi_{t} \quad$ : Variable-compensation payout ratio in period $\mathrm{t}$ 

6) $R E x_{\min (t)}$ : Lower limit for the executives' incentives in period $t$
7) $\overline{R E x_{\max (t)}}$ : Upper limit for the executives' incentives in period $\mathrm{t}$
8) $\operatorname{ldiv}_{t} \quad$ : Minimum dividend growth in period t over period t-1
9) $\varphi N I I_{t} \quad$ : Minimum revenue growth rate in period t over period t-1
10) $L R_{\min }:$ Lower limit for the loans ratio
11) $\overline{\overline{L R_{\max }}} \quad:$ Upper limit for the loans ratio
12) $\overline{L T D R_{t}} \quad:$ Permitted/required value of the loans to deposits ratio in period $\mathrm{t}$
13) $\varphi$ Assets $_{t}:$ Minimum assets growth rate in period $\mathrm{t}$
C. Economic parameters
1) $R_{f} \quad:$ Risk free rate
2) $\quad \beta \quad$ : Market risk
3) $\quad R_{m} \quad:$ Market return
4) $y_{i} \quad:$ The yield on the $\mathrm{i}^{\text {th }}$ asset
5) $i_{j} \quad:$ The interest rate on the $\mathrm{j}^{\text {th }}$ liability
6) $\tau_{t} \quad:$ The corporate tax rate in the period $\mathrm{t}$
7) $R O E_{\text {ind }(t)} \quad$ : Return on equity of the industry average in period $t$
8) $\quad N I M_{\text {ind }(t)} \quad$ : Net interest margin of the industry average in period $t$
9) $E R_{\text {ind }(t)} \quad$ Efficiency ratio of the industry average in period $\mathrm{t}$ 